\title{
ITGB6 wt Allele
}

National Cancer Institute

\section{Source}

National Cancer Institute. IT GB6 wt Allele. NCI Thesaurus. Code C124266.

Human IT GB6 wild-type allele is located in the vicinity of 2 q24.2 and is approximately 172 $\mathrm{kb}$ in length. This allele, which encodes integrin beta- 6 , is involved in cell matrix adhesion. Mutation of the gene is associated with amelogenesis imperfecta, type $\mathrm{IH}$. 